\title{
Research on the Cultivation of Students Practical Ability Majoring in Electronic Information Engineering under the Background of the Transformation and Development of Local Undergraduate Universities
}

\author{
Liu Fang \\ College of Physics and Electronic Information, Baicheng Normal University, Baicheng 137000, \\ China
}

email: bcsfxywlx@163.com

Keywords: Local; University; Transformation; Students; Practical ability

\begin{abstract}
With the rapid development of social economy, in order to better meet the market demand for talent, many local colleges and universities began the transformation and development, to the long-term development of all walks of life. Through training a lot not only mastered the theoretical knowledge, talents and has profound practical ability, the university can as China's economic progress, social stability, to provide help. Based on this, this paper on the current situation of local undergraduate colleges and universities talent practical ability were analyzed, combined with the transformation of school inquiry of the students' Professional College of electronic and information engineering, the way of cultivating the ability of practice.
\end{abstract}

\section{Introduction}

In the capacity of all aspects of the process of training students in undergraduate colleges focused on students' learning of theoretical knowledge, training analysis. Colleges training theory of a large number of talents, which makes the type of talent in the job market, facing many difficulties in the job. At the same time, with the China's accession to the world trade organization, the relation between the country, close up gradually, economic exchanges have become increasingly frequent, the theory of talent is difficult in the current economic exchanges, play strength. In addition, in many areas of personnel training in Colleges and universities, for training practical ability of the lack of attention students, lack of training opportunities, and schools for training students' practical ability in terms of capital and technology investment is less, students generally show [1]. practical ability is not ideal on the local colleges The electronic and information engineering, at this stage needs talent cultivation, transformation of culture in the development of University. Therefore, to find a theoretical and practical ability, to cultivate new way, make the students accept many in the cultivation of the innovation of practice ability, has become a rich professional the theory of knowledge, talent and practical ability, adapt to the market for the talent demand.

\section{Analysis of Problems Existing in the Practical Ability of College Students Majoring in Electronic Information Engineering}

Electronic and Information Engineering in universities is a professional has a very strong practical course. The purpose of this course is for students of knowledge theory of electronic information system training, after the training of students practical ability in practical operation. Then students can demand for talents in the job practice stage good adapt to the enterprise, broaden the students' job on the road [2]. According to the training status of the professional students in local colleges and universities at present that the cultivation of talents in comprehensive practice, there exist many problems, these problems need the timely detection and timely in the process of teaching, make a corresponding improvement, formed in line with the needs of the market cultivation mode practical talents. The specific problems are mainly manifested in the following three points. First of all, many colleges and universities, training of electronic information engineering specialty, there exists the problem of inaccurate positioning of personnel training. The professional training needs has certain practical ability, but some colleges and universities in training, the positioning theory research 
personnel for training the professional personnel training mode. This kind of electronic and Information Engineering there is a misunderstanding, the location of the school. Ignoring the need to define it as practical talents to training objectives, which leads to students with theoretical knowledge or unilateral ability, or has the technical ability, but the lack of guidance of theoretical knowledge. The talents cannot have the theory and practice in many aspects, to solve the problem of the comprehensive ability [3].Secondly, in the training school, the theory and practice of curriculum setting is not reasonable. At present many colleges and universities for students to carry out the teaching of theoretical knowledge, students' enthusiasm in learning is not high. If things go on like this the students will lose interest in the profession, the university personnel training. At the same time there is a bottleneck in less class time school practice courses, and the lack of professional practice teaching, lack of practice places, practice materials. Therefore students practice the theoretical knowledge of the application conditions, the practical ability is not optimistic. Finally, the shortage of teachers. Many teachers in the professional is just graduated from school students lack the ability to solve practical problems in enterprise work experience and processing. So in cultivating students' practical ability, is unable to do the empty talk, the students in the correct guidance. In addition, college of electronic and information engineering The students are lack of teaching, improving the evaluation of indicators, only from the student's test scores, papers published to determine whether students have mastered the practice ability, it is not scientific. The teacher ignored the students' learning process, the practice operation, the problem of evaluation of [4]. product development and other aspects of the ability of the existence of the local universities, the need for timely restructuring and development of personnel training methods, the final school students, it has the remarkable ability of practice.

\section{Analysis of Ways to Cultivate Students' Practical Ability in Electronic Information Engineering Specialty during the Transformation Stage}

Changing the Idea of Cultivating Talents' Practical Ability and Constructing a Scientific Teaching System of Electronic Information Engineering. At present, under the background of the development of practical training of the students, the school leadership is needed in local colleges, and the professional teaching staff to strengthen attention. In the process of personnel training, the school needs for personnel training objectives, and the teaching departments, discipline system, teaching content and for the scientific adjustment. This enables to cultivate talents with professional knowledge, talent and practical ability. In constructing a new teaching system, school needs in the teaching system, adding laboratory teaching, practical teaching links, and students in the four years of study, constantly on the two a part of the teaching practice time prolonged. So that students can grasp the basic foundation in electronic information engineering theory system, in the concrete practice, to learn the knowledge. Students can improve the analysis of problems to maximize the ability to deal with problems. At the same time in the teaching and practice of laboratory training, schools need to strengthen professional training equipment investment, and set up specialized laboratories and training places, for students of the corresponding practice. Students with practical ability four years of teaching, master the basic skills of electrical and electronic, basic computer skills, skills to assemble the electronic instrument and meter, meter fault detection circuit and analog circuit maintenance skills, basic analysis and other aspects of the operation ability. After training the skilled basic ability, training students again through the systematic practice master, a comprehensive analysis of practical ability and related electronic information system, finally causes the student in the system of practice, combining the theoretical knowledge to be learned through ability to solve practical problems [5].

Actively Carry out Production Training Activities in Personnel Training. After mastering the skills in local undergraduate students, schools need to give students sufficient time for production training activities. In practice, teachers improve students' hands-on ability, as well as the theoretical knowledge into practical skills, ability level. This training method in enhancing the current practice ability, play a key role. In Electronic Information Engineering Specialty training plan, the school has clearly pointed out the need to cultivate talents of practical skills. So based on the level of 
training, teachers should guide the students to CAD circuit design practice, and practice the MCU running function debugging circuit, and electronic instrument system connection and other exercises, and find the fault problems of some commonly used electronic devices. The practice of students in training, comprehensive of the contents of the practice, improve the ability of the operation, and the students in practice, according to the existing problems, the problems and causes of regional search in time, discuss the problems among the students to ask teachers or other forms, effectively solve, constantly in the process of finding and solving problems, for the theory of knowledge, deepen understanding, promote the steady improvement of practical ability .

Encourage and Guide Students to Participate in Specialized Electronic Design Competition. For students in training, the whole process of effective grasp of professional teachers in colleges and universities of electronic and information engineering to students. Students in strength permitting, teachers can guide students to active concern associated with the professional competitions. For example currently there is a high authoritative professional event - the National Undergraduate Electronic Design Contest. The competition is carried out, hands on students in electronic information engineering students' practical ability, innovation ability, theory grasp ability to carry out a comprehensive investigation. Therefore universities can in the student to the professional knowledge system of learning, let students actively participate in the competition in order to go on their own the professional practical ability test. Students, or students group, to contest topic, basic content, framework design after determined, teachers can give appropriate comment, when students, teachers can help the effective test of the electronic product performance. Therefore, participating in the preparation and production of a series of this process, the students, the relationship between teachers and students is shortened, so to establish a good relationship of cooperation between them, but also to promote the abilities of students the increased [6].

Implementation of School Enterprise Cooperation to Strengthen the Training of Practical Ability of Talents. Colleges and universities should actively provide work for electronic information engineering students platform, let students with the help of platform, related knowledge on their own, again for effective mastery. In practice, the students have the ability level. Therefore in the stage of transformation, local universities can strengthen the related local and electronic information engineering the area of business, the demand for professionals to understand the situation of enterprises. The school also need to strengthen the relationship with enterprises, establish the mode of cultivating the interest of both the school enterprise cooperation talents practice ability, let the students in the enterprise provides jobs. Through the practice of learning, students can do the production operation, improve the ability of practice. At the same time, in the school enterprise cooperation in the enterprise can also on the students' practical ability of study, which is good for The students, after graduation, recruitment to the enterprise, as the development of enterprises, creating new opportunities for development, staff enthusiasm greatly mobilize the enterprise, with the help of the fresh blood to promote long-term operation of enterprises, promote the stable and healthy development of the students' occupation road. So the electronic information engineering professional development school enterprise cooperation, not only provides a great help for the professional employment, while the students work in the enterprise, let the students on the current employment situation of the professional, and the professional talent cultivation to understand, finally could make the students in the workplace, effective accumulated working experience in the positive. The maximum improve students practical level, so that students can fully integrate their own ability, application in production in the development of enterprises, and continuously improve the enterprise competition Strength. In addition, universities and enterprises in the cooperation between the universities, enterprises can invite senior engineers, senior management personnel, to set students enterprise talent demand ability preaching, so that the students can learn the admission, in the beginning, for practical ability of learning plan, after the follow-up study in the full investment to improve the level of professional practice, so that students in the graduation, theory and practice have become common talent [7].

Set Up a Team of Teachers with a High Level of Teaching Ability. In the process of personnel training in Colleges and universities for teachers' teaching ability should be paid attention to. First 
of all, the school needs regular teaching ability of teachers evaluation, training, training, and constantly improve the teaching level of teachers, so that teachers can recognize themselves in the evaluation, in teaching, problems in training and education. In the activity, teachers actively learn the advanced teaching idea, technical means to carry out the modernization of teaching, in order to effectively attract the attention of students, so that students in the course of interest, better into the practice of curriculum learning. Secondly, the school should actively encourage teachers to carry out research and development project in the study, after reviewed by the laboratory data involved in the project, after writing academic papers, in order to improve the comprehensive ability of teachers, teachers can make in the future teaching, the students will have effective practice guidance.

\section{Conclusion}

In the current development, local colleges have been developing remarkable achievements. This makes the students in the school can be related to learning. This greatly contributed to the increase of our national quality and ability, but in practice the cultivation of talents, the school faces many difficulties. Therefore the school needs in this transformation, after the transformation of the development background, strengthen students' professional practice ability.

\section{References}

[1] Hong Yan. The training mode of Applied Talents in the context of the transformation and development of Local Undergraduate Universities [J]. curriculum education research, 2017, (07): 250.

[2] Chang Chao. Research on the innovation of applied talents training mode of social sports management in Local Universities under the background of Transformation Development -- Taking Xuchang University as an example [J]. Journal of Chifeng University (NATURAL SCIENCE EDITION), 2016,32 (24): 170-171.

[3] Ning Zhuzhu. Research on Application Oriented Curriculum Reform in Local Universities under the background of "transformation"[D].Shaanxi Normal University, $2016 .$.

[4] Haoli Luan. Reflections on the transformation and development of Local Universities[J]. Journal of Shenyang Institute of Engineering (SOCIAL SCIENCE EDITION), 2016,12 (02): 218-222.

[5] Wei Fan. Research on the path choice of the transformation development of local undergraduate colleges and universities [J]. Theory, 2015, (11): 151-152.

[6] Lv Xiuli, Mou Hedwig, Liu Xiang Lou, Han Jian, Yu Bo. The cultivation of innovation and practice ability of students majoring in electronic information engineering of $[\mathrm{J}]$. Education Forum, 2012, (38): 56-57.

[7], Luo Yingxiang, Tan Zefu. Training system and practice of innovative ability for students majoring in electronic information engineering [J]. Computer knowledge and technology, 2009,5 (33): 9461-9462. 